\title{
COMPARABLE PRESENTATION OF CARCASS AND MEAT QUALITY OF DIFFERENT PIG GENOTYPES USING MODERN EVALUATION METHODS**
}

\author{
O. Kosovac ${ }^{1 *}$, S. Josipović ${ }^{1}$, B. Živković ${ }^{1}$, Č. Radović ${ }^{1}$, \\ G. Marinkov ${ }^{1}$, D. Tomašević ${ }^{1}$ \\ ${ }^{1}$ Institute for Animal Husbandry, Belgrade-Zemun, Zemun 11080, Serbia \\ *Corresponding author, e-mail: galo@Eunet.yu, \\ ** Original scientific paper. Research financed by the Ministry of Science of Republic of \\ Serbia, Project BTN 351008 B
}

\begin{abstract}
In this paper quality of carcasses/carcass sides and meat from 5 different pig genotypes was comparably evaluated. Quality of carcass sides was evaluated prior to slaughtering in vivo (SONOMARK SM $100 \mathrm{M}$ ), early post mortem on slaughter line (FOM), by method of two points (ZP - ZWEIPUNKT) as well as method of partial dissection on cold left carcass sides according to EU recommendations. By analysis of obtained results it can be concluded that fatteners of type E (LW x SL) x P had the highest meat yield in carcass sides $(61,90 ; 62,40 ; 58,85$ and $58,89 \%)$ by any other mentioned methods of evaluation compared to average meat yield in carcass sides of other investigated genotypes. Average yield of muscle tissue in carcasses of pigs of E genotype (LW x SL) x P $(58,89 \%)$ established by method of partial dissection was statistically considerably higher $(* p<0,05)$ than the average $(56,06 \%)$ meat yield in carcasses of pigs of genotype D, very significantly higher $(* * p<0,01)$ than average $(57,01 \%)$ meat yield in carcasses of pigs of genotype $\mathrm{C}$ and very highly significantly higher $(* * * p<0,001)$ than average $(51,30 \%)$ meat yield in carcasses of pigs of genotype A.

The quality of meat was also investigated comparably by determining its technological quality and chemical composition of MLD in investigated genotypes of pigs. Technological quality and chemical composition of MLD demonstrated significant $\left({ }^{*} \mathrm{p}<0,05\right)$ differences in $\mathrm{WBC}$ and pigment content between genotypes $\mathrm{B}$ and $\mathrm{C}$ and $\mathrm{B}$ and $\mathrm{E}$. Average values for content of ashes and share of pigment are in accordance with average values which characterize muscles of normal traits.

By analysis of obtained results we conclude that fatteners of genotype $\mathrm{E}$ (LW x SL) x P had the highest meat yield in carcass sides $(61,90 ; 62,40$;
\end{abstract}


58,85 and $58,89 \%$ ), but quality was slightly decreased which indicates need for further improvement of meat quality.

Key words: pigs, quality of carcass/carcass sides and meat, evaluation methods.

\section{Introduction}

Quantity of produced meat is important element of production, although its precedence has for longer period been superseded. In developed countries there is agreement according to which quality of meat is of higher importance and represents competitive advantage, and quantity is one of the integral elements of the quality (Zekić et al. 2007).

Considering that the »quantity is one of the integral elements of quality«, in order to evaluate objectively the quality of pig carcasses, in EU countries as well as in Serbia many researches were undertaken relating to quality of carcass and meat of pigs (Timanović 2003; Džinić et al., 2003; Fisher et al., 2003; Tomović et al., 2003; Pulkrảbek et al., 2003; Džinić et al., 2004; Bahelka et al., 2004; Džinić 2005; Jukna and Jukna 2005; Zekić et al., 2007).

In order to increase the production volume and quality of meat, more attention is directed to determination of quality of pig carcass on live animals prior to slaughtering in-vivo (PIGLOG 105, SONOMARK SM 100 $\mathrm{M}$ ), early post mortem on slaughter line (FOM), by method of two points (ZP - ZWEI-PUNKT) and method of partial dissection on cooled left carcass sides according to EU recommendations, and based on this method the carcasses are categorized according to standard (S E U R O P).

Considering above mentioned, objective of this paper was to present the carcass and meat quality of pigs of different genotypes by applying modern evaluation methods.

\section{Material and methods}

Evaluation of carcass quality was performed on 5 pig genotypes, one group was pure breed Swedish Landrace (SL, group A; $n=20$ ), two return mating combinations (Large White $\mathrm{x}$ Swedish Landrace) $\mathrm{x}$ Large White (F1 $\mathrm{x}$ LW, group $\mathrm{B} ; \mathrm{n}=19$ ), (Large White $\mathrm{x}$ Swedish Landrace) $\mathrm{x}$ Swedish Landrace (F1 x SL, group C; $\mathrm{n}=30$ ) and two combinations of three breed pig hybrids: (Large White x Swedish Landrace) x Duroc (LW x SL) x D, group 
D; $n=22$ and (Large White $x$ Swedish Landrace) x Pietrain (LW x SL) x P, group $\mathrm{E} ; \mathrm{n}=25$.

On total of 116 carcasses the quality of carcass sides was determined, i.e. yield of meat in carcass sides and class (S E U R O P) on farm in-vivo, using SONOMARK SM 100 M (SM). Apparatus/device SM is used for determination of quality of carcasses/carcass sides, i.e. meat yield in carcasses/carcass sides on live animals on basis of so called A mode of ultrasound impulses which are presented on scale and this enables measuring in vivo of fat and muscle tissue thickness of pigs and directly is displayed in $\mathrm{mm}$. Then, on warm right carcass sides, using FOM apparatus (Petrović et al., 1996) and by method of two points (ZP-Zwei-Punkte), linear multiple regression model with two independent variables, and the defined model was verified in accordance with EU Regulations: No 3127/94 (RMSE<2,5\%). The model defined in Serbia by Džinić et al. (2004) was used. Dissection of cold $\left(+4^{\circ} \mathrm{C}\right)$ right carcass sides was done according to method determined by Walstra and Merkus (1996) and classes according to S E U R O P.

Quality of cooled meat was investigated by determination of water and free fat content using reference method (1998). Content of total ashes was determined by method of stoking (1999). Water binding ability was determined according to method by Grau and Hamm (1953) and expressed in \% of bound water, and colour of meat was determined based on absorption of water meat extract according to Hart (Rede and Rahelić 1969 a). Total pigments were determined according to method by Horsney (Rede and Rahelić 1969b). Statistical processing of data was done using computer programme Stat. Soft. 7.1 (2007).

\section{Results and Discussion}

Average values of meat content in carcasses of investigated genotypes obtained by different methods are presented in table 1. It is obvious from results that carcass sides of pigs of genotype $\mathrm{E}$ are superior, regardless of the investigation method. Also it is obvious that fatteners of genotype E (LW x SL) $\mathrm{x} P$ had the highest meat yield in carcass sides also regardless of the method of investigation $(61,90 ; 62,40 ; 58,85$ and $58,89 \%)$ compared to fatteners of other investigated genotypes. Differences in average yield of meat determined by method of partial dissection between genotypes A and $\mathrm{D}$ were significant $(* p<0,05), A$ and $C(* * p<0,01)$ and $A$ and $E(* * * p<0,001)$. Our data on yield of muscle tissue in carcass sides of investigated genotypes obtained by FOM and method of partial dissection are within the limits of 
results obtained by Fisher et al. (2003), Timanović (2003), Džinić et al.(2003), Tomović et al.(2003), Džinić (2005).

Table 1. Average content of meat (\%) in carcass sides determined using different methods

\begin{tabular}{|c|c|c|c|c|c|c|c|c|c|}
\hline Genotype & Indicator & $\begin{array}{c}\text { Sono } \\
\text { Mark }\end{array}$ & Class & FOM & Class & $\begin{array}{c}\text { Dissection } \\
\text { acc. to EU }\end{array}$ & Class & $\begin{array}{c}\text { Two } \\
\text { points }\end{array}$ & Class \\
\hline $\mathrm{A}$ & $\mathrm{X}$ & $\begin{array}{c}56,76^{\mathrm{AB}, \mathrm{b}} \\
3,53\end{array}$ & $\mathrm{E}$ & $\begin{array}{c}55,52^{\mathrm{ab}, \mathrm{d}} \\
3,00\end{array}$ & $\mathrm{E}$ & $\begin{array}{c}51,30^{\mathrm{yAB}, \mathrm{D}, \mathrm{b}} \\
1,60\end{array}$ & $\mathrm{U}$ & $\begin{array}{c}55,36^{\mathrm{b}} \\
2,02\end{array}$ & $\mathrm{E}$ \\
\hline $\mathrm{B}$ & $\mathrm{X}$ & $\begin{array}{c}58,18^{\mathrm{AB}, \mathrm{ab}} \\
0,67\end{array}$ & $\mathrm{E}$ & $\begin{array}{c}55,60^{\mathrm{b}, \mathrm{cd}} \\
2,73\end{array}$ & $\mathrm{E}$ & $\begin{array}{c}53,45^{\mathrm{xyB}, \mathrm{CD}, \mathrm{ab}} \\
3,87\end{array}$ & $\mathrm{U}$ & $\begin{array}{c}56,38^{\mathrm{ab}} \\
1,18\end{array}$ & $\mathrm{E}$ \\
\hline $\mathrm{Cd}$ & $\mathrm{X}$ & $\begin{array}{c}59,13^{\mathrm{AB}, \mathrm{ab}} \\
4,01\end{array}$ & $\mathrm{E}$ & $\begin{array}{c}60,37^{\mathrm{ab}, \mathrm{cd}} \\
4,58\end{array}$ & $\mathrm{~S}$ & $\begin{array}{c}57,01^{\mathrm{xAB}, \mathrm{C}, \mathrm{ab}} \\
2,68\end{array}$ & $\mathrm{E}$ & $\begin{array}{c}57,95^{\mathrm{ab}} \\
2,16\end{array}$ & $\mathrm{E}$ \\
\hline $\mathrm{D}$ & $\mathrm{X}$ & $\begin{array}{c}56,22^{\mathrm{B}, \mathrm{ab}} \\
\mathrm{Sd}\end{array}$ & $\mathrm{E}$ & $\begin{array}{c}57,76^{\mathrm{ab}, \mathrm{cd}} \\
4,64\end{array}$ & $\mathrm{E}$ & $\begin{array}{c}56,06^{\mathrm{xyAB}, \mathrm{CD}, \mathrm{a}} \\
1,73\end{array}$ & $\mathrm{E}$ & $\begin{array}{c}56,59^{\mathrm{ab}} \\
1,96\end{array}$ & $\mathrm{E}$ \\
\hline $\mathrm{E}$ & $\mathrm{x}$ & $\begin{array}{c}61,90^{\mathrm{A}, \mathrm{a}} \\
1,22\end{array}$ & $\mathrm{~S}$ & $\begin{array}{c}62,40^{\mathrm{a}, \mathrm{c}} \\
3,47\end{array}$ & $\mathrm{~S}$ & $\begin{array}{c}58,85^{\mathrm{xA}, \mathrm{CD}, \mathrm{ab}} \\
2,94\end{array}$ & $\mathrm{E}$ & $\begin{array}{c}58,89^{\mathrm{a}} \\
2,11\end{array}$ & $\mathrm{E}$ \\
\hline
\end{tabular}

a,b,c,d- significance at the level $0,05 \quad(* \mathrm{p}<0,05)$

A,B,C,D- significance at the level $0,01(* * p<0,01)$

$\mathrm{x}, \mathrm{y}$ - significance at the level $0,001 \quad(* * * \mathrm{p}<0,001)$

Percentage of meat in carcass sides determined using Two Point System varied from 55,36\% (genotype A) to $58,89 \%$ (genotype E). Three breed hybrids with Pietrain (genotype E) had considerably higher $(* p<0,05)$ meat yield in carcass sides compared to pure breed pigs of Swedish Landrace (genotype A).

Table 2. Correlation coefficients between relative meat yield in carcass sides, determined by method of partial dissection and other investigated methods $n=116$

\begin{tabular}{|c|c|c|}
\hline \multicolumn{3}{|c|}{ PARTIAL DISSECTION } \\
\hline SONOMARK & FOM & TWO POINTS \\
\hline 0,23 & 0,54 & 0,43 \\
\hline
\end{tabular}

Our results are in accordance with results obtained by Zekić et al. (2007) who established in their investigative evaluation of the carcass side quality using Two Point method average percentage of meat in carcass sides of $56,20 \%$, and it varied from $48,09 \%$ (R class) to $62,61 \%$ (S class), and according to Pulkrảbek et al. (2003) value of average meat content was $54,36 \%$. 
Correlations between \% of meat determined by partial dissection and using SM, FOM and method of Two Points are presented in table 2, and are mainly low and within limits of 0,23 do 0,54 .

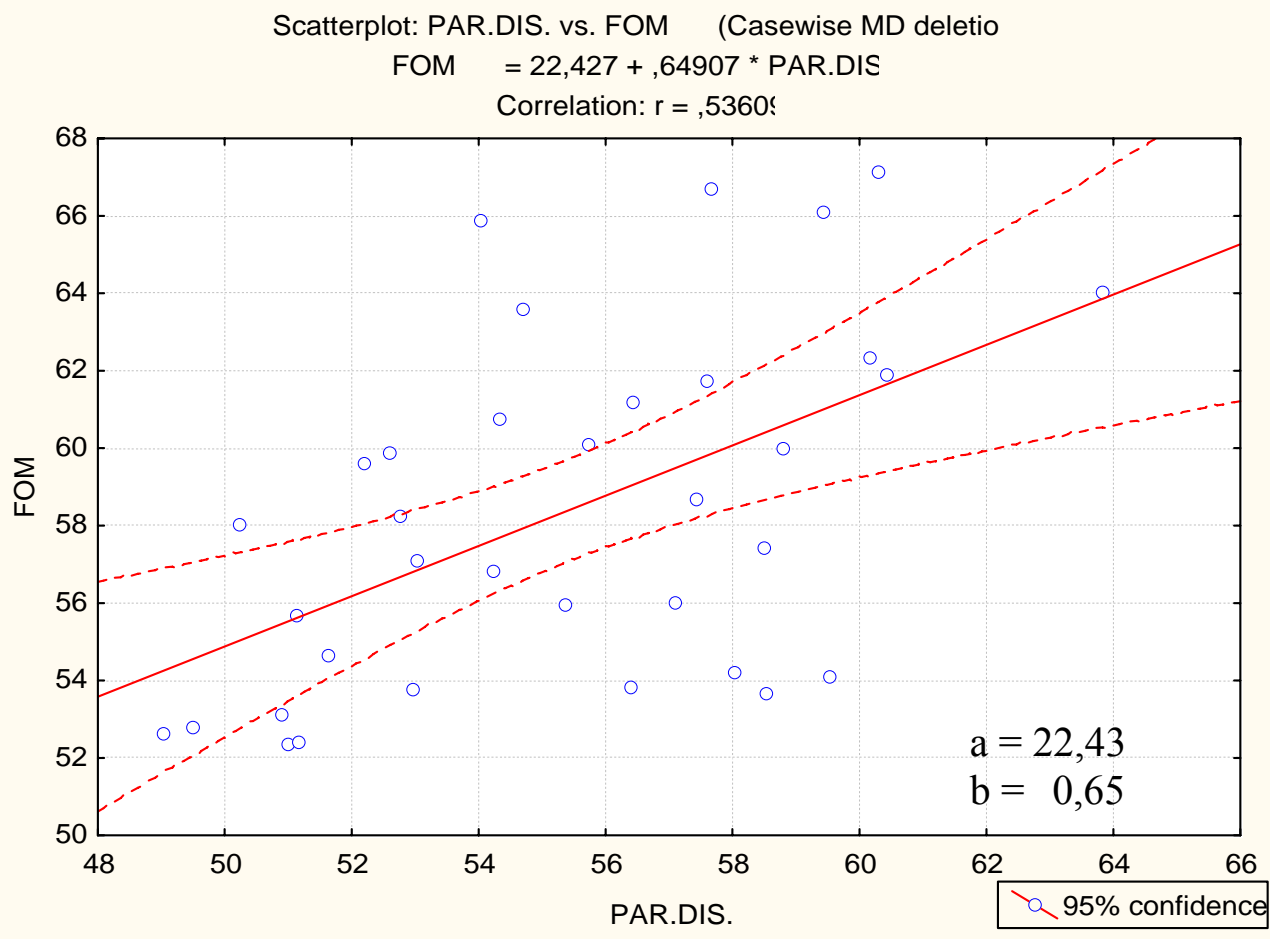

Graph 1. Graphical presentation of regression of share of meat in carcass determined by mathematical model FOM and method of partial dissection

$$
Y=22,43+0,65 x
$$

Bahelka et al. (2005) established that correlations between content of meat determined by dissection and evaluated by two point method were statistically significant and negative $(\mathrm{r}=-0,84$ to $-0,97)$ which was confirmed by research of Pulkrảbek et al. (2003). In our research, slightly higher correlation coefficient between \% of meat determined by partial dissection and FOM was established - 0,54 (graph 1). Stated investigation results are not in accordance with results stated by Timanović (2003), Džinić et al. (2004), Džinić (2005), Brkić et al. (2001) who obtained results justifying the 
use of ultrasound apparatus PIGLOG 105, and that the most optimal measuring should be performed at the body mass of 100-120 kg. However, in our investigations, obtained correlations between meat content determined by dissection and using SM apparatus were low - 0,23.

In table 3 results relating to technological quality and chemical composition of MLD are presented. Although in absolute values difference in values obtained by study of the water content, as well as values determined for colour, these differences weren't statistically significant $(\mathrm{P}>0,05)$.

Table 3. Mean values of results of investigation of certain indicators of technological quality and chemical composition of MLD in investigated pig genotypes

\begin{tabular}{|c|c|c|c|c|c|c|c|c|}
\hline \multirow{2}{*}{ Genotype } & \multirow{2}{*}{ No. } & \multirow{2}{*}{ Indicator } & \multicolumn{3}{|c|}{ Chemical composition \% } & \multirow{2}{*}{$\begin{array}{c}\text { WBA } \\
\%\end{array}$} & \multirow{2}{*}{ Colour } & \multirow{2}{*}{$\begin{array}{c}\text { Total } \\
\text { pigments } \\
\mu \mathrm{g} / 100 \mathrm{~g}\end{array}$} \\
\hline & & & Water & Fat & Ashes & & & \\
\hline \multirow{2}{*}{$\mathrm{A}$} & \multirow{2}{*}{20} & $\mathrm{x}$ & 73,60 & $1,64^{\mathrm{ab}, \mathrm{cd}}$ & 1,15 & $48,27^{\mathrm{ab}, \mathrm{cd}}$ & 0,68 & $28,80^{\mathrm{ab}}$ \\
\hline & & $\mathrm{Sd}$ & 0,50 & 0,57 & 1,25 & 4,13 & 1,09 & 4,78 \\
\hline \multirow{2}{*}{ B } & \multirow{2}{*}{19} & $\mathrm{x}$ & 73,68 & $1,65^{\mathrm{ab}, \mathrm{cd}}$ & 1,11 & $53,55^{\mathrm{a}, \mathrm{c}}$ & 0,43 & $29,30^{\mathrm{a}}$ \\
\hline & & $\mathrm{Sd}$ & 0,88 & 0,74 & 0,02 & 5,38 & 0,07 & 6,28 \\
\hline \multirow{2}{*}{$\mathrm{C}$} & \multirow{2}{*}{30} & $\mathrm{x}$ & 73,98 & $2,17^{\mathrm{ab}, \mathrm{d}}$ & 1,11 & $46,68^{\mathrm{ab}, \mathrm{d}}$ & 0,28 & $21,90^{b}$ \\
\hline & & $\mathrm{Sd}$ & 1,63 & 0,60 & 0,04 & 2,78 & 0,08 & 4,32 \\
\hline \multirow{2}{*}{ D } & \multirow{2}{*}{22} & $\mathrm{x}$ & 73,63 & $2,19^{b, c d}$ & 1,14 & $51,04^{\mathrm{ab}, \mathrm{cd}}$ & 0,33 & $27,36^{\mathrm{ab}}$ \\
\hline & & $\mathrm{Sd}$ & 1,26 & 0,63 & 0,05 & 5,95 & 0,11 & 5,00 \\
\hline \multirow{2}{*}{$\mathrm{E}$} & \multirow{2}{*}{25} & $\mathrm{x}$ & 74,01 & $1,22^{\mathrm{a}, \mathrm{c}}$ & 1,17 & $46,50^{\mathrm{b}, \mathrm{cd}}$ & 0,27 & $23,66^{\mathrm{ab}}$ \\
\hline & & $\mathrm{Sd}$ & 0,88 & 0,46 & 0,05 & 0,99 & 0,02 & 3,76 \\
\hline
\end{tabular}

a,b,c,d - significance at the level $0,05(* \mathrm{p}<0,05)$

Meat of pigs of three breed combination with Pietrain (LW x SL) x P (genotype E) had the lowest share of free fats, the least expressed colour and the lowest WBA, and higher share of ashes compared to results of other investigated genotypes $(1,22 ; 0,27 ; 46,50$ and 1,17$)$.

In research by Timanović (2003), Džinić et al. (2003), Džinić et al. (2004), Tomović et al .(2003) and Jukna and Jukna (2005) obtained results for most of the traits of technological quality and chemical composition were similar to results obtained in our research.

Correlation coefficients between \% of meat determined by method of partial dissection and some indicators of technological quality and chemical composition of meat of investigated genotypes are presented in table 4 and are mainly low. Only the correlation coefficient determined between 
percentage of meat and content of colour in meat from pigs of genotype $\mathrm{E}$ was established to be higher - 0,78.

Table 4. Correlation coefficients ( $r$ ) between $\%$ of meat in carcass sides (dissection) and some indicators of technological quality and chemical composition of MLD in investigated pig genotypes

\begin{tabular}{|c|c|c|c|c|c|c|}
\hline Genotype & Water & Fat & Ashes & WBA & Colour & $\begin{array}{c}\text { Total } \\
\text { pigments }\end{array}$ \\
\hline A & $-0,12$ & $-0,24$ & $-0,47$ & $-0,50$ & $-0,55$ & 0,47 \\
\hline B & 0,51 & 0,08 & $-0,28$ & 0,21 & $-0,44$ & $-0,27$ \\
\hline C & 0,37 & $-0,29$ & 0,17 & 0,08 & $-0,20$ & $-0,40$ \\
\hline D & $-0,20$ & 0,64 & 0,37 & $-0,19$ & 0,26 & 0,37 \\
\hline E & $-0,24$ & 0,17 & 0,03 & $-0,46$ & 0,78 & $-0,65$ \\
\hline
\end{tabular}

\section{Conclusion}

Based on results of comparative study of the quality of carcass sides and meat of 5 pig genotypes, in vivo (SM), on slaughter line (FOM), by method of two points (ZP), on cold carcass sides (partial dissection), as well as comparative investigation of the technological quality and chemical composition of MLD of investigated genotypes, the following can be concluded:

Fatteners of genotype E (LW x SL) x P had the highest yield of meat in carcasses/carcass sides $(61,90 ; 62,40 ; 58,85$ and 58,89\%) regardless of the evaluation method used compared to average yield of meat in carcass sides of other investigated genotypes.

Average meat yield in carcass sides of pigs of genotype E (LW x SL) x P $(58,89 \%)$ established by use of method of partial dissection was statistically considerably higher $\left({ }^{*} p<0,05\right)$ than average $(56,06 \%)$ meat yield in carcass sides of pigs of genotype $\mathrm{D}$, very significantly higher $(* * \mathrm{p}<0,01)$ than average $(57,01 \%)$ meat yield in carcass sides of pigs of genotype $\mathrm{C}$ and very highly significantly higher $(* * * p<0,001)$ than average $(51,30 \%)$ meat yield in carcass sides of pigs of genotype A.

Established regression equation resulted in better evaluations for pigs with meat content of 55,52\% and more, with correlation coefficient $(0,78)$ between relative meat yield in carcass sides determined by method of partial dissection and FOM. Therefore, this method is suitable for evaluation of 
carcass side quality on slaughter line, and for future progress in pig production it will be necessary to introduce the evaluation of carcass side quality on slaughter line and in this way satisfy criteria set by EU.

Technological quality and chemical composition of MLD exhibited significant $\left({ }^{*} \mathrm{p}<0,05\right)$ differences in regard to WBA and pigment content between genotypes $\mathrm{B}$ and $\mathrm{C}$ and $\mathrm{B}$ and $\mathrm{E}$.

\title{
UPOREDNI PRIKAZ KVALITETA SVINJSKIH TRUPOVA PRIMENOM NEKIH SAVREMENIH METODA OCENE
}

\author{
O. Kosovac, S. Josipović, B. Živković, Č. Radović, G. Marinkov, \\ D. Tomašević
}

\section{Rezime}

U radu je izvršeno komparativno ocenjivanje kvaliteta trupova/polutki i mesa 5 različitih genotipova svinja.

Kvalitet polutki ocenjen je na živim životinjama pre klanja in-vivo SONOMARK SM $100 \mathrm{M}$ ), rano post mortem na liniji klanja (FOM), metodom dve tačke (ZP - ZWEI-PUNKT) kao i metodom parcijalne disekcije na ohladjenim levim polutkama po preporuci EU. Analizom dobijenih rezultata može se zaključiti da su tovljenici genotipa E (VJ x ŠL) x P imali najveći prinos mesa u polutkama $(61,90 ; 62,40 ; 58,85$ i 58,89\%) pri korišćenju bilo koje od navedenih metoda ocene u poredjenju sa prosečnim prinosom mesa u polutkama svinja ostalih ispitivanih genotipova. Prosečan prinos mišićnog tkiva u trupovima svinja genotipa $\mathrm{E}$ (VJ x ŠSL) x P $(58,89 \%)$ ustanovljen primenom metode parcijalne disekcije statistički značajno veći $\left({ }^{*} \mathrm{p}<0,05\right)$ od prosečnog $(56,06 \%)$ prinosa mesa u trupovima svinja genotipa $\mathrm{D}$, vrlo značajno veći $(* * \mathrm{p}<0,01)$ od prosečnog $(57,01 \%)$ prinosa mesa $\mathrm{u}$ trupovima svinja genotipa $\mathrm{C}$ i vrlo visoko značajno veći $(* * * \mathrm{p}<0,001)$ od prosečnog $(51,30 \%)$ prinosa mesa u trupovima svinja genotipa $\mathrm{A}$.

Ispitan je komparativno i kvalitet mesa odredjivanjem tehnološkog kvaliteta $\mathrm{i}$ hemijskog sastava MLD-a ispitivanih genotipova svinja Tehnološki kvalitet i hemijski sastav mesa MLD-a ispolio je značajne $\left({ }^{*} \mathrm{p}<0,05\right)$ razlike u SVV i sadržaju pigmenata izmedju genotipova B i C i B i E. Prosečne vrednosti za sadržaj pepela i udeo pigmenata odgovara 
prosečnim vrednostima koje karakteriše mišiće normalnih svojstava.

Analizom dobijenih rezultata zaključujemo da su tovljenici genotipa E (VJ x ŠL) x P imali najveći prinos mesa u polutkama $(61,90 ; 62,40 ; 58,85$ $\mathrm{i} 58,89 \%$ ), no nešto umanjenog kvaliteta, što iziskuje dalji rad na poboljšanju kvaliteta mesa.

Ključne reči: svinje, kvalitet trupa/polutki i mesa, metode ocene

\section{References}

BAHELKA I., DEMO P., PEŠKOVIČOVÁ D. (2005): Pig carcass classification in Slovakia-New formulas for two point method and measuring instruments. Biotechnology in Animal Husbandry 21 (5-6), 181-185.

BAHELKA I., DEMO P., PEŠKOVIČOVÀ R. (2004): Optimalizảcia regresných rovnic pre klasifikảciu ošipaných $\mathrm{v}$ SR. Zborník príspevkov z medzinárodnej vedeckej konferencie, Brno, Czech Republic, $17^{\text {th }}$ September, 138-141.

BRKIĆ N., STOJIĆ P., PETROVIĆ M., KANIS E. (2001): Povezanost izmedju debljine slanine i dubine MLD-a na živim grlima i totalnoj disekciji.Biotehnologija u stočarstvu 17 (5-6), .307.

COMMISSION REGULATION (EC) No 3127/94 of 20 December 1994 amending Regulation (EC) No 2967/85 laying dowd detailed rules for the application of the Community scale for grading pig carcases (1994): Official Journal of the European Communities No L 330, 21/12/1994, 43-44.

COUNCIL REGULATION (EEC) No 3220/84 of 13 November 1984 determining the Community scale for grading pig carcass (1984): Official Journal of the European Communities No L 301, 20/11/1984, 1-3.

DŽINIĆ N. (2005): Uticaj endogenih i egzogenih faktora na kvalitet mesa svinja. Doktorska disertacija. Univerzitet u Banja Luci, Banja Luka.

DŽINIĆ N., PETROVIĆ LJ., MANOJLOVIĆ D., TOMOVIĆ V., TIMANOVIĆ S., TRIŠIĆ-ILIĆ S. i KURJAKOV N. (2001): U Proc. $47^{\text {th }}$ ICoMST, »Future of Meat«, Krakow, Poland, Vol.I, 2-P19, 146-147.

DŽINIĆ N., PETROVIĆ LJ., TOMOVIĆ V., MANOJLOVIĆ D. (2004):« Definisanje matematičkog modela za utvrdjivanje prinosa mesa u polutkama svinja metodom dve tačke«, Simpozijum: »Veterinarstvo i stočarstvo u proizvodnji zdravstveno bezbedne hrane«, Zbornik kratkih sadržaja, Herceg Novi, 28.

DŽINIĆ N., PETROVIĆ LJ., TOMOVIĆ V., MANOJLOVIĆ D., TIMANOVIĆ S., VIDANIĆ D., KURJAKOV N. (2003): Ocena kvaliteta 
polutki i mesa svinja rasa veliki jorkšir i švedski landras. Biotehnologija u stočarstvu 19, (5-6), 500.

DŽINIĆ N., PETROVIĆ LJ., TOMOVIĆ V., MANOJLOVIĆ D., TIMANOVIĆ S., TRIŠIĆ-ILIĆ S. i MRDJANOV JELENA (2003): Uticaj višerasnog ukrštanja i godišnjeg doba na kvalitet polutki i mesa svinja. Savremena poljoprivreda, 52, (3-4) str. 335-337.

FISHER A.V., GREEN D.M., WHITTEMORE C.T., WOOD J.D., SCHOFIELD C.P. (2003): Growth of carcass components and its relation with conformation in pigs of three types. Meat Science, 65, 1, 639-650.

GRAU R., UND HAMM R. (1953): Eine einfache Methode zur Bestimmung der Wasserbindung im Muskel. Naturwissenschaften, 40, 29-30.

JUKNA V., JUKNA C. (2005): The comparable estimatimation of meat quality of pigs breeds and their combinations in Lithuania. Biotechnology in Animal Husbandry 21 (5-6), p. 175-179.

JUS ISO 1442 (1998)- Odredjivanje sadržaja vode

JUS ISO 1444 (1998) -Odredjivanje sadržaja slobodne masti.

JUS ISO 936 (1999) - Odredjivanje sadržaja pepela.

PETROVIĆ LJ. (rukovodilac projekta) (2000): Razvoj sistema za ocenu kvaliteta trupova na liniji klanja svinja prema zahtevima standarda za ocenu kvaliteta serije ISO i JUS 9000 i EN 45000.Završni izveštaj o realizaciji istraživačko-tehnološkog projekta S.4.28.50.0037.NOVOTEH 2000, katalog rezultata, Beograd.

PETROVIĆ LJ., MANOJLOVIĆ D., DINIĆ N., LATOVSKA E., VELIMIR J., ADAMOVIĆ J. (1996): Evaluation of carcass and meat quality on the slaughterline of pigs with FOM-device. 12nd ICoMST, Proceedings, G-7, 246. lillehammer, Norway.

PULKRÀBEK J., PAVLIK J., VALIŠ L., ČECHOVẢ M. (2003): Pig carcass classification based on the Iean meat content. Sbornik Mendlovy zemědělskẻ a lesnickẻ univerzity, Brno, 51, 109-113.

REDE R., RAHELIĆ S. (1969a): Priručnik za pregled i fizičko-hemijska ispitivanja $\mathrm{u}$ industriji mesa. Tehnologija mesa.

REDE R., RAHELIĆ S. (1969b): Priručnik za pregled i fizičko-hemijska ispitivanja u industriji mesa. Tehnologija mesa.

TIMANOVIĆ S. (2003): Efekat različitih modela selekcije i šema ukrštanja na prinos i kvalitet mesa svinja. Doktorska disertacija, Poljoprivredni fakultet, Novi Sad.

TOMOVIĆ V.(2002): Uticaj selekcije i višerasnog ukrštanja svinja na kvalitet polutki i tehnološki, nutritivni i senzorni kvalitet mesa. Magistarski rad. Tehnološki fakultet, Novi Sad. 
TOMOVIĆ V., PETROVIĆ LJ., DŽINIĆ N., MANOJLOVIĆ D., TIMANOVIĆ S., VIDARIĆ D., KURJAKOV N. (2003):Kvalitet polutki i mesa svinja trorasnih hibrida. Savremena poljoprivreda, 52, 3-4, str. 369371.

WALSTRA, P., and MERKUS, G.S.M.(1996): Procedure for assessment of the lean meat percentage as cosequence of the new EU reference dissection method in pig carcass classification, Researsch Institute for Animal Science and Health Report,ID-DLO 96.014, 1-22, Research Branch, Zeist, The Netherlands.

ZEKIĆ V, OKANOVIĆ DJ., ŽIVKOVIĆ B. (2007): Ekonomski aspekti proizvodnje svinjskog mesa. Savremena poljoprivreda 56, 1-2, str. 206-211. 